\title{
Diyabetik Ayak Gelişimini Önleyici Hasta Eğitim Programının Hastaların Ayak Bakımı ile İlgili Bilgi ve Uygulamalarına Etkisi
}

\author{
Hatice TEL AYDIN ${ }^{1} \oplus$, Pelin ÇELIK ${ }^{2}$ ๑ $ه$ \\ ${ }^{1}$ Sivas Cumhuriyet Üniversitesi, Sağlık Bilimleri Fakültesi, İç Hastalıkları Hemşireliği Anabilim Dalı, Sivas, Türkiye \\ ${ }^{2}$ Sivas Cumhuriyet Üniversitesi, Sağlık Hizmetleri Meslek Yüksekokulu, Sivas, Türkiye \\ Bu çalışma, 5. Uluslararası 16. Ulusal Hemşirelik Kongresi, 6 Kasım 2017, Ankara'da sözlü bildiri olarak sunulmuştur.
}

Bu makaleye yapılacak atıf: Tel Aydın H, Çelik P. Diyabetik Ayak Gelişimini Önleyici Hasta Eğitim Programının Hastaların Ayak Bakımı ile İlgili Bilgi ve Uygulamalarına Etkisi. Türk Diyab Obez 2020;2: 90-97.

\section{ÖZ}

Amaç: Tip 2 diyabetli hastalarda, diyabetik ayak gelişmesini önleyici hasta eğitim programının, hastaların ayak bakımı ile ilgili bilgi ve uygulamaları üzerine etkisini incelemektir.

Gereç ve Yöntemler: Ön test-son test desende planlanan araştırma, bir üniversite hastanesinin Genel Dahiliye Kliniğinde yapılmıştır. Araştırmanın örneklemini, Tip 2 diyabet tanısı ile hastanede yatmakta olan, 18 yaş ve üstü, hastaneye yattığında ayakta ülser veya enfeksiyon bulunmayan, bilinci açık, iletişim kurmaya engel teşkil edecek bir durumu olmayan, iletişimi engelleyecek bir durumu olmayan, yazılı onayı alınan 40 hasta oluşturmuştur.

Bulgular: Araştırmaya alınan hastaların \%62,5’inin kadın, \%30’unun 60 ve üzeri yaş grubunda, \%25’inin 20 yıldan fazla süredir Tip2 DM tanısı olduğu ve \%37,5’unun ayak yarası öyküsü olduğu belirlenmiştir. Eğitim öncesinde hastaların diyabetik ayak gelişmesini önleme doğru davranışları yapma oranlarının büyük oranda düşük olduğu, eğitim sonrası değerlendirmede doğru davranışları yapma oranlarının anlamlı şekilde arttığı belirlenmiştir.

Sonuç: Diyabetik ayak gelişmesini önleyici eğitim programının Tip2 DM tanılı hastaların ayak bakımına ilişkin doğru bilgi ve davranış kazanmalarında etkili olduğu belirlenmiştir.

Anahtar Sözcükler: Diyabet, Diyabetik ayak, Hemşirelik

\section{The Effect of Preventive Patient Educational Program About Diabetic Foot Development on Patients' Knowledge and Practice of Foot Care}

\begin{abstract}
Aim: The aim of this study is to investigate the effect of the patient education program to pre-venting the development of diabetic foot on the knowledge and practices of foot care in patients with type 2 diabetes.

Material and Methods: The research planned in the pre-test and post-test design was conducted in the General Internal Clinic of a university hospital. The sample of the study consisted of 40 patients who were hospitalized with the diagnosis of Type 2 diabetes, aged 18 and over, who had no ulcers or infections on their foot when they were hospitalized, were conscious, had no condition to prevent communication, and had written consent.

Results: It was found that $62.5 \%$ of the patients included in the study were female, $30 \%$ were in the age group of 60 and above, $25 \%$ had been diagnosed with Type 2 DM for more than 20 years and $37.5 \%$ had a foot wound history had a history of foot injury (injury yaralanma anlamı verdiği için wound ayak ülser yarası için daha uygun). Before the training, It was determined that while the rate of doing the right behaviors to prevent the develop-ment of diabetic foot was significantly lower before the training, and the rate of perfor-ming the correct behaviors in the post-training period increased significantly.

Conclusion: Diabetic foot development training program was found to be effective in gaining the right informa-tion and behaviors related to foot care in patients with Type $2 \mathrm{DM}$.
\end{abstract}

Key Words: Diabetes, Diabetes, Diabetic foot, Nursing

ORCID: Hatice Tel Aydın / 0000-0002-1518-8080, Pelin Çelik / 0000-0002-1179-4227 


\section{GİRIS}

Diabetes Mellitus (DM), insülin eksikliği ve/veya etkisizliği sonucu meydana gelen, kan şekeri yüksekliği ile karakterize metabolik bir hastalıktır. Diyabet dünya genelinde hızlı bir şekilde yayılması, tüm yaş gruplarında görülme sıklığının artması, akut ve kronik komplikasyonlara neden olması, organlarda geriye dönüşümü olmayan hasara yol açması, tedavi maliyetinin yüksek olması ve en önemli ölüm nedeninden birisi olması nedeniyle küresel bir halk sağlığ sorunudur $(1,2)$. Uluslararası Diyabet Federasyonuna (IDF) göre, dünyada 20-79 yaş grubunda tahmini 463 milyon diyabet hastası olduğu, 2045 yılında bu sayının 700 milyona ulaşacağ 1 tahmin edilmektedir (3). Ülkemizde ise, IDF verilerine göre, 2019 y1l itibariyle 6.6 milyon diyabetli birey bulunduğu ve bu oranın ülkemizin \%12'sini temsil ettiği ifade edilmektedir (3).

Gelecek yıllarda tüm dünyada olduğu gibi bizim ülkemizde de diyabet prevalansının artması ile diyabetik ayak ülserlerinin sıklığı da artacaktır $(4,5)$. Diyabetin komplikasyonlarından biri olan nöropati ve diyabete sıklıkla eşlik eden periferik arter hastalığının sonucu gelişen iskemi zemininde, aşırı basınç yükü ve enfeksiyonun da eklenmesi ile diyabetik ayak oluşur. Diyabetik ayak, organ kaybına neden olan, ruhsal, bedensel, sosyal ve ekonomik etkileri olan önemli bir komplikasyondur (6-8). Diyabetik hastalarda görülen en yaygın ayak problemleri ayak ülseri ve enfeksiyondur (9). IDF verilerine göre; dünya üzerinde 40-60 milyonluk bir kesimin diyabetik ayak ve diğer alt ekstremite sorunları yaşadığı tahmin ediliyor. IDF'e göre bu oran, diyabete bağlı kronik ülserler ve ampütasyon ihtiyaçlarının oluşmasıyla erken ölümlere de neden olmaktadır (3). Diyabetli hastalar için ayak ülseri riski \%15-25 oranında olup, alt ekstremite ampütasyonlarının \%40-70’i diyabete bağlı gelişmekte, travmatik olmayan amputasyonların \%50-70'i diyabetik hastalarda yapılmaktadır (7, 10-12). Etkili önlemlerin alınması, iyi bir hasta eğitimi, sağlık çalışanlarının duyarlılığı, eğitim, düzenli izlem ve glisemik kontrol ile diyabetik ayak ampütasyonlarının azaltılması mümkün olmaktadır $(13,14)$. Diyabetli hastanın, günlük diyabet yönetimini başarılı bir şekilde gerçekleştirebilmesi için yeterli bilgi, beceri ve olumlu tutumlara sahip olmasi gerekmektedir $(15,16)$. Diyabetli bireylere verilecek eğitimde bilgi sağlamanın yanı sıra, diyabete uyum ve davranış değişikliği kazandırmanın da hedeflenmesi gerekir (17). Diyabet komplikasyonlarının önlenmesi ile sıkı glisemik kontrol ve iyi koordine edilmiş hastalık yönetimi arasında yaşamsal bir ilişki olduğu tüm dünyanın üzerinde uzlaştığı bir görüştür (18). Etkin bir hasta eğitimi diyabet tedavisinin en önemli basamaklarındandır (19-22). Araștırmanın amacı, diyabetik ayak gelişimini önleyici hasta eğitim programının, tip 2 diyabetli hastaların ayak bakımı ile ilgili bilgi ve uygulamaları üzerine etkisini incelemektir.

\section{GEREÇ ve YÖNTEMLER}

Araştırmanın örneklemini, Mayıs-Ekim 2015 dönemleri arasında bir üniversite hastanesi Dahiliye Kliniğinde, Tip 2 diyabet tanısı ile yatmakta olan, 18 ve üstü yaş grubunda, hastaneye yatışında ayakta ülser veya enfeksiyon bulunmayan, bilinci açık, iletişimi engelleyecek bir durumu olmayan, yazılı onayı alınan 40 hasta oluşturmuştur. Araştırma Cumhuriyet Üniversitesi Girişimsel Olmayan Klinik Araştırmalar Etik Kurlu 17.04.2015 tarihli ve 2015-04/11 Karar nolu olurları sonrası gerçekleştirilmiştir. Ön test-son test desende gerçekleştirilen araştırmada; hastaların eğitim uygulanmadan önceki bulguları ön test verilerini, eğitim uygulandıktan sonraki bulguları son test verilerini oluşturmuştur. Araştırma verilerinin toplanmasında araştırmacılar tarafından literatür doğrultusunda hazırlanan anket formu kullanılmıştır. Anket formunda, hastaların sosyo-demografik özellikleri, hastalık özellikleri ile ayak bakımı ile ilgili bilgi ve uygulamalarının belirlenmesini amaçlayan sorular yer almaktadır. Hastaların mevcut durumu ve eğitim ihtiyacı belirlendikten sonra araştırmacı tarafından hastalara diyabetik ayak gelişmesini önleyici eğitim programı uygulanmıştır. Eğitim içeriği konuyla ilgili literatürden yararlanarak hazırlanan eğitim materyali doğrultusunda uygulanmıştır. Eğitimde; diyabetin nasıl bir hastalık olduğu, en önemli komplikasyonu/istenmeyen sonuçları, diyabetik ayak komplikasyonunun nedenleri, nasıl geliştiği ve diyabetik ayak gelişimini önlemek için nelere dikkat edilmesi gerektiği konularına yer verilmiştir. Eğitim, hastalara hastanede yattıkları süre içinde araştırmacı tarafından, bireysel eğitim şeklinde uygulanmıştır. Eğitim oturumlarında yazılı ve görsel eğitim materyalleri kullanılarak, soru-cevap şeklinde özetlemeler yapılarak hastaların aktif katılımı sağlanmıştır. Hastaların diyabetik ayak gelişimini önlemeye yönelik eğitim içeriğinde öğrendikleri bilgileri ve diyabetik ayak gelişimini önlemeye yönelik uygulamaları yapma durumları, hastaneden taburcu olmalarını takip eden birinci ve üçüncü aylarda değerlendirilmiştir. Belirtilen değerlendirmeler hastalarla yapılan telefon görüşmeleri yoluyla gerçekleștirilmiştir. Hasta tanıtım formunda yer alan metabolik göstergeler için, hastaların rutin sağlık kontrollerinde yapılan test sonuçları kullanılmıştır. Çalışmaya alınan hastaların diyabetik ayak gelişmesini önleyici uygulamaları yapıp yapmama durumları Diyabetik Ayak Yarası ve İnfeksiyonunun Tanısı, Tedavisi ve Önlenmesi: Ulusal Uzlaşı Raporu Raporu'nda (2015) belirtilen, diyabetik ayak yarası ve enfeksiyonunun tanisı, tedavisi ve önlenmesi ile ilgili olarak yapılması gereken, davranış ve tutumlar doğrultusunda değerlendirilmiştir (4).

\section{Verilerin Analizi}

Araştırma sonucunda elde edilen sayısal veriler, aritmetik ortalama \pm standart sapma; sözel veriler, sayı ve yüzde 
şeklinde gösterilmiştir. Diğer verilerin analizinde ise, ikiden fazla tekrarlanan bağımlı örneğin karşılaştırılmasında öncelikle Cochran Q testi kullanılarak bağımlı grupların frekanslarının birbirlerinden önemli farklılık gösterip göstermediği test edilmiştir. Fark bulunduğunda ise, hangi gruptan kaynaklandığını belirlemek için Bonferroni düzeltmeli Mc Nemar testi kullanılmıştır. Sonuçlar Bonferroni düzeltmesinde bilinen anlamlılık sınırı (yani $\mathrm{p}<0,05)$ karşılaştırma sayısına bölünerek, yeni anlamlılık sinırı 0,05/3=0,016 olarak belirlenmiştir.

\section{BULGULAR}

Araştırmaya alınan hastaların \%62,5'inin kadın, \%30'unun 60 ve üzeri yaş grubunda, \%25'inin 20 ylldan fazla süredir Tip2 DM tansına sahip olduğu belirlenmiştir. Hastaların \%45'inin (18 hasta) diyabet, \%27,5'inin (11 hasta) diyabetik

Tablo 1: Hastaların sosyodemografik ve hastalık durumu ile ilgili özellikleri.

\begin{tabular}{|c|c|c|}
\hline Demografik Özellikler & & $\begin{array}{c}\text { Olgu Sayıs1 } \\
\text { n (\%) }\end{array}$ \\
\hline \multicolumn{3}{|l|}{ Cinsiyet } \\
\hline Kadın & & $25(62,5)$ \\
\hline Erkek & & $15(37,5)$ \\
\hline \multicolumn{3}{|l|}{ Yaş } \\
\hline $30-40$ & & $4(10,0)$ \\
\hline $41-50$ & & $10(25,0)$ \\
\hline $51-60$ & & $14(35,0)$ \\
\hline $61-70$ & & $12(30,0)$ \\
\hline \multicolumn{3}{|l|}{ Diyabet Süresi } \\
\hline 1-5 y1l arası & & $8(20,0)$ \\
\hline $6-20$ yıl arası & & $22(55,0)$ \\
\hline 20 yildan fazla & & $10(25,0)$ \\
\hline \multicolumn{3}{|c|}{ Diyabet Hakkında Bilgi Alma } \\
\hline Evet & & $18(45,0)$ \\
\hline Hayır & & $22(55,0)$ \\
\hline \multicolumn{3}{|c|}{ Diyabetik Ayak Hakkında Bilgi Alma } \\
\hline Evet & & $11(27,5)$ \\
\hline Hayır & & $29(72,5)$ \\
\hline \multicolumn{3}{|l|}{ Ayak Yarası Öyküsü } \\
\hline Evet & & $15(37,5)$ \\
\hline Hayır & & $25(62,5)$ \\
\hline \multicolumn{3}{|l|}{ BKİ değeri } \\
\hline 18.50-24.99 Normal & & $3(7,5)$ \\
\hline >25.00 Hafif şişman & & $18(45,0)$ \\
\hline$>30.00$ Obez & & $19(47,5)$ \\
\hline $\bar{x} \pm$ S.s & $28,75 \pm 3,78$ & \\
\hline \multicolumn{3}{|c|}{ Son Ölçülen HbA1c Değeri } \\
\hline$\leq \% 7.9$ & & $10(25,0)$ \\
\hline$\% 8-9.9$ & & $8(20,0)$ \\
\hline$\geq \% 10$ & & $22(55,0)$ \\
\hline $\bar{x} \pm$ S.s & $9,53 \pm 1,80$ & \\
\hline \multicolumn{3}{|l|}{ Son Ölçülen AKŞ Değeri } \\
\hline$<200 \mathrm{mg} / \mathrm{dl}$ & & $18(45,0)$ \\
\hline $200-300 \mathrm{mg} / \mathrm{dl}$ & & $21(52,5)$ \\
\hline$>300 \mathrm{mg} / \mathrm{dl}$ & & $1(2,5)$ \\
\hline $\bar{x} \pm$ S.s & $196,65 \pm 46,05$ & \\
\hline
\end{tabular}


ayak hakkında bilgi aldığını ifade ettikleri ve $\% 37,5$ 'unun ayak yarası öyküsü olduğu saptanmıştır (Tablo 1). BKI ortalamasına göre hastalarının \%47,5'nin obez olduğu, \%52,5'inin AKŞ değerinin 200-300 mg/dl ve \%55,0'inin $\mathrm{HbA1c}$ değerinin \%10 ve üzerinde olduğu belirlenmiştir.

Hastaların diyabetik ayak eğitimi uygulanmadan önce diyabetik ayak gelişimini önleyici uygulamaları yapma durumları değerlendirildiğinde; hastaların hiçbirinin ayaklarını günlük yara, kesik, çizik, ezik açısından kontrol etmediği, \%20'sinin ayak tırnaklarında kalınlaşma, renk değişikliği ve batma kontrolünü yaptığı; \%7,5’inin ayaklarını günlük 10-15 dakika ılık su banyosu yaptırıp parmak aralarını dikkatlice kurulama işlemini yaptığı, \%15'inin ayaklarını temizlerken kullandığı suyun ısısını kontrol ettiği, \%10'unun ev içinde ya da dışında (deniz kenarında, kumda, toprakta, sert betonda) çıplak ayakla dolaşmamaya dikkat ettiği, \%17,5’inin ayağında nasır, kabarcık olduğunda doktora başvurduğu, \%45,0'inin ayaklarında kuruma, çatlama oldu-

Tablo 2: Eğitim öncesi ve sonrasında diyabetli hastaların ayak bakımı ile ilgili davranışları doğru yapma durumları.

\begin{tabular}{|c|c|c|c|c|c|c|c|c|c|c|c|c|c|}
\hline \multirow{3}{*}{ Davranışlar } & \multicolumn{4}{|c|}{$\begin{array}{c}\text { Ĕgitim öncesi } \\
\text { değerlendirme(1) }\end{array}$} & \multicolumn{4}{|c|}{$\begin{array}{c}\text { Eğitim sonrası } \\
\text { 1. ay değerlendirme(2) }\end{array}$} & \multicolumn{4}{|c|}{$\begin{array}{c}\text { Eğitim sonrası } \\
\text { 3. ay değerlendirme(3) }\end{array}$} & \multirow{3}{*}{$\begin{array}{c}p \\
p_{1=} 1-2 \\
p_{2=} 1-3 \\
p_{3=} 2-3\end{array}$} \\
\hline & \multicolumn{2}{|c|}{ Doğru } & \multicolumn{2}{|c|}{ Yanlış } & \multicolumn{2}{|c|}{ Doğru } & \multicolumn{2}{|c|}{ Yanlış } & \multicolumn{2}{|c|}{ Doğru } & \multicolumn{2}{|c|}{ Yanlış } & \\
\hline & $\mathbf{n}$ & $\%$ & $\mathbf{n}$ & $\%$ & $\mathbf{n}$ & $\%$ & $\mathbf{n}$ & $\%$ & $\mathbf{n}$ & $\%$ & $\mathbf{n}$ & $\%$ & \\
\hline $\begin{array}{l}\text { Ayakları günlük yara, kesik, } \\
\text { çizik, ezik açısından kontrol } \\
\text { etmek }\end{array}$ & - & - & 40 & 100,0 & 11 & 27,5 & 29 & 72,5 & 15 & 37,5 & 25 & 62,5 & $\begin{array}{l}\mathrm{p}_{1=} 0,001^{\star} \\
\mathrm{p}_{2=} 0,001^{\star} \\
\mathrm{p}_{3=} 0,125\end{array}$ \\
\hline $\begin{array}{l}\text { Ayak tırnaklarında } \\
\text { kalınlaşma renk değişikliği ve } \\
\text { batma kontrolü yapmak }\end{array}$ & 8 & 20,0 & 32 & 80,0 & 20 & 50,0 & 20 & 50,0 & 20 & 50,0 & 20 & 50,0 & $\begin{array}{l}\mathrm{p}_{1=} 0,001^{\star} \\
\mathrm{p}_{2=} 0,001^{\star} \\
\mathrm{p}_{3=} 1,000\end{array}$ \\
\hline $\begin{array}{l}\text { Ayakları her gün yıkayıp } \\
\text { kurulamak }\end{array}$ & 3 & 7,5 & 37 & 92,5 & 12 & 30,0 & 28 & 70,0 & 18 & 45,0 & 22 & 55,0 & $\begin{array}{l}\mathrm{p}_{1=} 0,004^{*} \\
\mathrm{p}_{2=} 0,001^{\star} \\
\mathrm{p}_{3=} 0,031\end{array}$ \\
\hline $\begin{array}{l}\text { Ayağını yıkadığı suyun ısısını } \\
\text { kontrol etmek }\end{array}$ & 6 & 15,0 & 34 & 85,0 & 15 & 37,5 & 25 & 62,5 & 18 & 45,0 & 22 & 55,0 & $\begin{array}{l}\mathrm{p}_{1=} 0,035 \\
\mathrm{p}_{2=} 0,008^{*} \\
\mathrm{p}_{3=} 0,250\end{array}$ \\
\hline $\begin{array}{l}\text { Ayakkabı giymeden içini } \\
\text { yabancı cisim açısından } \\
\text { kontrol etmek }\end{array}$ & 3 & 7,5 & 37 & 92,5 & 15 & 37,5 & 25 & 62,5 & 16 & 40,0 & 24 & 60,0 & $\begin{array}{l}\mathrm{p}_{1=} 0,001^{\star} \\
\mathrm{p}_{2=} 0,001^{\star} \\
\mathrm{p}_{3=} 1,000\end{array}$ \\
\hline Ayağını 1sıtma şekli & 30 & 75,0 & 10 & 25,0 & 37 & 92,5 & 3 & 7,5 & 38 & 95,0 & 2 & 5,0 & $\begin{array}{l}\mathrm{p}_{1=} 0,016^{*} \\
\mathrm{p}_{2=} 0,008^{*} \\
\mathrm{p}_{3=} 1,000\end{array}$ \\
\hline $\begin{array}{l}\text { Çıplak ayak dolaşmamaya } \\
\text { dikkat etmek }\end{array}$ & 4 & 10,0 & 36 & 90,0 & 30 & 75,0 & 10 & 25,0 & 32 & 80,0 & 8 & 20,0 & $\begin{array}{l}\mathrm{p}_{1=} 0,001^{\star} \\
\mathrm{p}_{2=} 0,001^{\star} \\
\mathrm{p}_{3=} 0,500\end{array}$ \\
\hline Çorap seçimi & 36 & 90,0 & 4 & 10,0 & 40 & 100,0 & - & - & 40 & 100,0 & - & - & $\begin{array}{l}\mathrm{p}_{1=} 0,125 \\
\mathrm{p}_{2=}=125\end{array}$ \\
\hline Ayakkabı seçimi & 20 & 50,0 & 20 & 50,0 & 37 & 92,5 & 3 & 7,5 & 37 & 92,5 & 3 & 7,5 & $\begin{array}{l}\mathrm{p}_{1=} 0,001^{\star} \\
\mathrm{p}_{2=} 0,001^{\star} \\
\mathrm{p}_{3=} 1,000\end{array}$ \\
\hline $\begin{array}{l}\text { Ayakta nasır, kabarcık } \\
\text { olduğunda doktora } \\
\text { başvurmak }\end{array}$ & 7 & 17,5 & 33 & 82,5 & 32 & 80,0 & 8 & 20,0 & 34 & 85,0 & 6 & 15,0 & $\begin{array}{l}\mathrm{p}_{1=} 0,001^{\star} \\
\mathrm{p}_{2=} 0,001^{\star} \\
\mathrm{p}_{3=} 0,500\end{array}$ \\
\hline Ayak tabanını kontrol etmek & - & - & 40 & 100,0 & 9 & 22,5 & 31 & 77,5 & 12 & 30,0 & 28 & 70,0 & $\begin{array}{l}\mathrm{p}_{1=}=0,004^{*} \\
\mathrm{p}_{2=} 0,002^{\star} \\
\mathrm{p}_{3=} 1,000\end{array}$ \\
\hline
\end{tabular}

${ }^{\star} \mathbf{p} \leq \mathbf{0 . 0 1 6}, \mathbf{p}_{\mathbf{1}=}$ (Eğitim öncesi- Eğitim sonrası 1. Ay değerlendirme), $\mathbf{p}_{2=}$ (Eğitim öncesi- Eğitim sonrası 3. Ay değerlendirme)

$\mathbf{p}_{3=}$ (Eğitim sonrası 1. Ay değerlendirme- Eğitim sonrası 3. Ay değerlendirme) 
ğunda yumuşatıcı merhemler kullandığı ve hiçbirinin ayak tabanını ayna ile kontrol etmediği belirlenmiștir (Tablo 2).

Diyabetik ayak eğitimi uygulandıktan sonraki 1. ve 3. ayda hastaların diyabetik ayak gelişimini önleyici uygulamaları yapma durumları değerlendirildiğinde; hastaların ayaklarını günlük yara, kesik, çizik, ezik açısından kontrol etme $\left(\mathrm{p}_{1=} 0,001\right.$ ve $\left.\mathrm{p}_{2=} 0,001\right)$; ayak tırnaklarında kalınlaşma, renk değişikliği ve batma kontrolünü doğru yapma $\left(\mathrm{p}_{1=} 0,001\right.$ ve $\left.\mathrm{p}_{2=} 0,001\right)$; ayaklarına günlük 10-15 dakika ılık su banyosu yapıp parmak aralarını dikkatlice kurulama işlemini doğru yapma $\left(\mathrm{p}_{1=} 0,004, \mathrm{p}_{2=} 0,001\right)$; ayakların temizlerken kullandığı suyun 1 sısını kontrol etme işlemini doğru yapma $\left(\mathrm{p}_{2=} 0,008\right)$ oranlarının eğitim öncesine göre arttığ 1 ve bu artışın istatistiksel olarak anlamlı olduğu bulunmuştur $(\mathrm{p} \leq 0,016)$ (Tablo 2). Yine diyabetik ayak eğitimi uygulandıktan sonraki 1. ve 3. ayda; hastaların ayakkabı giymeden önce içini yabancı cisim, çivi başı, dikiş kabarıklıkları, kösele kıvrımı açısından kontrol işlemini doğru yapma $\left(\mathrm{p}_{1=} 0,001, \mathrm{p}_{2=} 0,001\right)$; ev içinde ya da dışarıda ( deniz kenarında, kumda, toprakta, sert betonda) çıplak ayakla dolaşmama ( $\left.\mathrm{p}_{1=} 0,001, \mathrm{p}_{2=} 0,001\right)$; ayağını doğru yöntemleri kullanarak 1sitma $\left(\mathrm{p}_{1}=0.016, \mathrm{p}_{2=} 0,008\right)$; ayakkabı seçimini doğru yapma $\left(\mathrm{p}_{1=} 0,001, \mathrm{p}_{2=} 0,001\right)$; ayaklarında kuruma, çatlama olduğu zaman yumuşatıcı merhemler kullanma $\left(\mathrm{p}_{1=} 0,001\right.$, $\left.\mathrm{p}_{2=} 0,001\right)$; ayak tabanını ayna ile kontrol etme $\left(\mathrm{p}_{1=} 0,004\right.$, $\left.\mathrm{p}_{2=} 0,002\right)$ oranlarının eğitim öncesine göre arttığı ve bu artışın istatistiksel olarak anlamlı olduğu bulunmuştur $(\mathrm{p}<0,016)$ (Tablo 2). Diyabetik ayak eğitimi sonrası 1. ve 3. aylar arasında, hastaların diyabetik ayak gelişimini önleyici uygulamaları yapma durumları değerlendirildiğinde; uygulamaların hiçbirinde anlamlı bir artış oranı bulunamamıştır ( $>0$,016) (Tablo 2).

\section{TARTIŞMA}

Diyabetik ayak, hastanede yatış süresinin uzamasına, iş gücü kaybına, sakatlıklara, psikososyal travmaya ve sağlık bakım maliyetinin artmasına yol açan önemli sağlık sorunlarından birisidir $(4,8)$. Diyabetli hastalara verilen eğitimler, diyabetik ayak yaralarının oluşmasını önlenmede ve tedavi edilmesinde oldukça önemlidir. Nijerya'da 2010 yilında yapılan bir çalışmada hastaların \% 92'sinin diyabete ilişkin hiç eğitim almadığı (23), başka bir çalışmada ise, hastaların çoğunun ayaklarında oluşan yaraların zor iyileştiğini ve bu durumla nasıl baş edecekleri hakkında bilgilerinin olmadığı ve bilgi almak istedikleri saptanmıştır (24). Çalışmamızda da yalnızca $11(\% 27,5)$ hastanın diyabetik ayak hakkında bilgi almış olduğu ve hastaların tamamının diyabetik ayakla ilgili eğitim almak istedikleri belirlenmiştir.

Türkiye Endokrinoloji ve Metabolizma Derneği, Diabetes Mellitus ve Komplikasyonları Tanı, Tedavi ve İzlem Kıla- vuzu-2019'da; glisemik hedeflerin bireyselleștirilmesi ve Tip 1 ve tip 2 diyabetli hastalarda, hipoglisemi riskini artıran özel bir durum yoksa, yaşam beklentisi yeteri kadar uzun ise, mikrovasküler komplikasyonların azaltılması için A1C hedefinin $\leq \% 7(53 \mathrm{mmol} / \mathrm{mol})$ olarak belirlenmesinin tercih edilmesi gerektiğini belirtmektedir. HbAlc ölçümleri, diyabetin izlenmesinde ve plazma glikoz seviyesi ile komplikasyonların gelişmesi arasındaki durumun belirlenmesinde oldukça önemlidir (25). Çalışmamızda hastaların $\% 52,5$ 'i 10 yıl ve daha fazla süredir diyabet tanısı almış, 55,0 'i HbAlc $\geq \% 10$ olan, \%52,5'i açlık kan şekeri değerleri 200-300 mg/dl arasinda olan, \%47,5'i obez olan bireylerden oluşmaktadır. Yapılan çalışmalarda, diyabetik ülserasyon oluşan hastaların, HbAlc seviyelerinin hedef düzeylerden yüksek olduğu belirtilmektedir $(26,27)$. Ancak ayak bakımına ilişkin eğitim alan ve buna uyum gösteren kişilerin HbA1c düzeyinin daha düşük olduğu da gösterilmiştir (28).

Diyabetik ayak oluşumunu önlemede anahtar yaklaşım, hasta eğitimidir. Eğitimlerde, hastalara ayna kullanarak ayak tabanını düzenli olarak kontrol edilmesi, kallus veya deride çatlak oluşup oluşmadığını izlenmesi, küçük boyuttaki yaraların uygun temizliğinin sağlanması, genel olarak ayak temizliğine dikkat edilmesi, tırnakların bakımı ve kesimine özen gösterilmesi, uygun ve rahat çorap ve ayakkabı seçimine dikkat edilmesi ve iyi bir ayak bakımının gerekliliği anlatılmalıdır (4). Uygun olmayan ayakkabı kullanımı ve yetersiz ayak ve tırnak bakımı, ayak problemleri gelişme riskini artırabilir (18). Güner'in çalışmasında, düzenli olarak ayak kontrolünü yapan hastaların \% 68,9'unun ayağında gelişen nasır, çatlak ve renk değişikliklerini farkettiği, \% 2,2'sinin ayak tabanını kontrolünü ayna ile yaptığı, $\%$ 27,8'inin nemlendirici veya pudra kullandığ 1 belirlenmiştir (29). Çalışmamızda eğitim öncesi değerlendirmede diyabetik ayak gelişmesini önlemek için yapılması gereken uygulamaların hastalar tarafindan yapılma oranının daha önceki çalışma sonuçlarına benzer olarak düşük olduğu, eğitimden sonraki izlemlerde hastaların uygulamaları doğru şekilde yapma oranlarının anlamlı şekilde arttığı belirlenmiştir. Bu sonuç, hemşire tarafından verilen bireysel eğitimin ve eğitim sonrası yapılan izlemin tip2 diyabet tanılı hastaların diyabetik ayak gelişini önleyici bakım uygulamalarını doğru yapma oranlarını desteklediğini ve artırdığını göstermektedir.

Ayak bakımı hakkındaki yanlış uygulamalar, ayakta ülserasyon gelişmesine zemin hazırlamaktadır. Diyabette her gün temiz, pamuklu, yünlü açık renk çoraplar giyilmesi, çorapların çok sıkı olmamasına dikkat edilmesi önerilmektedir $(4,24)$. Çalışmamızda çorap seçimini doğru yapan hasta oranındaki artış istatistiksel olarak anlamsız bulunsa da, tüm hastalarda ayak sağlığı için uygun çorap seçimi 
hakkında tutum değişikliği sağlanmıştır. Çalışmamızda hastaların eğitim öncesinde ayak hijyenine ilişkin, yeterli bilgiye sahip olmadıkları, diyabetik ayak bakımına ilişkin hiç eğitim almayan hasta sayısının $(29 ; \% 72,5)$ fazla olduğu tespit edilmiştir. Policarpo ve ark.'nin, çalışmalarına benzer olarak Kartal ve ark.'nın, tip2 diyabetli hastaların bakım ve tedaviye yönelik tutumlarını inceleyen çalışmalarında hastaların bakım ve tedaviye yönelik tutumlarının düşük olduğunu belirtmektedir $(27,30)$.

Çalışmamızda diyabetik ayak eğitimi sonunda, üşüyen ayağını çorap giyerek 1sıtma şeklinde doğru yöntemi kullanan hasta sayısı ile banyodan sonra ayak tırnaklarının etrafında kızarıklık, şişlik olup olmadığı kontrol edilerek, tırnakların yumuşakken düz kesilmesi ve tırnak köşelerinin derin alınmaması, zımparalı bir tırnak törpüsüyle törpülenmesi şeklinde doğru uygulama yapan hasta oranında istatistiksel olarak anlamlı artış belirlenmiştir (4). Güner yaptığı çalışmada hastaların \%84,4'ünün ayağı üşüdügünde çorap giyerek 1sıttığı, \%58,9'unun ayak tırnaklarını düz ve çok kısaltmadan, \%76,7'si kanatmadan kestiği belirtmiştir (29).

Çalışmaya katılan hastaların 25 'inde $(\% 62,5)$ ayak yarası öyküsü mevcut olup, diyabetik ayak eğitimi sonunda ayaklarında nasır, kallus, herhangi bir kabarcık olduğunda doktora başvurarak, doğru yöntemle tedavisini sağlayan hasta sayısında artış gözlenmiştir. Göç çalışmasında, ayaklarında yara oluştuğu zaman hastaların \% 40 'ının doktora veya sağlık kurumuna başvurduğunu, \%60'ının yara iyileşmez ise doktora başvurduğunu, Nural ve Hintistan çalışmalarında, hastaların \%17,6'sinın yara tedavisini kendi kendine yapt1ğını ve \%16,2'sinin ayağında gelişen yarayı önemsemediğini belirtmiştir $(24,31)$. Diyabetik ayak ülserlerinin altında yatan nedenlerin irreversibl, kronik ve progresif olduğu ve diyabetik ayak ülser gelişme oranının 5 yılda $\% 70$ olduğu belirtilmektedir (21). Bu durum hastalarda fiziksel yeti yitimine ve yaşam kalitesinde belirgin bir azalmaya yol açmaktadır. Bu nedenle diyabetik ayak ülseri öyküsü olan hastalar diyabetik ayak polikliniklerinde takip edilmeli ve hasta kendi kendine ayak muayenesine teşvik edilerek öz bakım yeteneği kazandırılmalıdır $(24,32)$. Hemşireler, hastalarda ortaya çıkabilecek olası sorunları değerlendirerek, hastanın öz bakım davranışlarını ve bilgisini iyileştirmelidir.

Diyabetik hastalarda ayakkabılar ayağa uygun ve rahat olmalıdır. Dar ayakkabılar kesinlikle kullanılmamalıdır. Ayakkabıların içi giymeden önce yabancı cisim, batıcı madde, pürüzlü yüzey, yırtık açısından her zaman kontrol edilmelidir ve çıplak ayakla kesinlikle yürünmemelidir $(4,24)$. Çalışmamızda diyabetik eğitimi sonunda, ayakkabı seçimini doğru yapan hasta sayısında ve ev içinde ya da dışarıda çıplak ayakla dolaşan hasta sayısı oranlarında istatistiksel olarak anlamlı değişimler gözlenmiştir. Güner yaptığı çalışmada, hastaların \%81,1'inin ayakkabılarını özel ve uygun olarak seçtiklerini, \%30'unun ayakkabılarını giymeden önce kontrol ettiğini, \%65,6'sının evde veya dışarıda yalınayak dolaştıklarını, \%53,3'ünün ayakkabı ya da terliklerini çorapsız olarak giydiklerini bildirmektedir (29).

Dünya Sağlı Örgütü (WHO) diyabetik ayak ülserlerinin etkili bir şekilde önlenmediğinde veya yönetilmediğinde diyabetli hastalar arasında engellilikle, ölümle ve önemli maliyetlerle sonuçlanacağını belirtmektedir (1). Diyabet kronik bir hastalıktır ve yaşam kalitesinin artması için tüm kronik hastalıklarda olduğu gibi hastaların eğitimleri önemlidir. Ancak ülkemizde hasta eğitiminin önemine son yllar içerisinde önem verilmeye başlanmıştır. Bu yüzden de özellikle kronik hastalıklı hastalarda, hastalıklara bağlı komplikasyonlar sık yaşanmaktadır. Çalışmamızda diyabetik ayak eğitimi öncesinde hastaların 32 'sinde $(\% 80,0)$ ayakta uyuşma, yanma ve karıncalanma şikayeti varken, taburculuk sonrası 1. ve 3. aylarda yapılan değerlendirmede 33 $(\% 82,5)$ hastada bu şikayetler olduğu saptanmıştır. Diyabeti olan hastaların \%60'ında periferik nöropati vardır ve hastalığın süresi uzadıkça gelişme olasılığı artar (4). Diyabetlilerde periferik nöropati, periferik arter hastalığ 1 ve infeksiyona yatkınlık nedeniyle ayak ülserleri ve nihayetinde amputasyonlar sık görülmektedir. Çalışmalar, travmatik nedenler dışında, ayak amputasyonuna yol açan sebeplerin \%60'ının diyabetten kaynaklandığını göstermektedir (32). Diyabetlilerin \%15-20'si hayatlarının bir döneminde ayak ülseri komplikasyonu yaşamaktadır. Bir kez ayak ülseri gelişen hastalarda bu sorunun tekrarlama olasılığ $1 \mathrm{da}$ yüksektir. Diyabetik ayak yarasının eğitimle ve basit önlemlerle önlenmesi, sorunun tedavisinden çok daha kolaydır (33). Fujiwara ve ark. yapmış oldukları çalışmada, diyabetli hastalarda hemşirelik temelli ayak bakım programının kallus gelişimi ve tinea pedis skorunu azalttı̆̆ 1 ve diyabetik ayağı önlemede etkili olduğu belirtilmektedir (25). Ayrıca amputasyonla sonuçlanan olgularda da yaşam kalitesi belirgin şekilde azalmakta ve iş gücü kayıpları ile birlikte ciddi sorunlar da ortaya çıkmaktadır (34). Adiewere ve ark. eğitim müdahalesinin, diyabetik ayak ülserlerinin insidansının azalmasında etkili olduğunu belirtmiştir (19).

Diyabetik ayak sorunları önlenebilir komplikasyonlar olup; tanıdan itibaren düzenli izleme ve diyabetlilerin eğitilerek koruyucu davranışların kazandırılmasında hemşirenin rolü önemlidir. Hastalığın başarılı bir biçimde tedavi ve izlenmesinde hastanın etkin rolünün sağlanabilmesi için hasta eğitimi ve hastanın kendi kendine yardımı öğrenmesi büyük önem taşımaktadır.

Çalışmamızda eğitim öncesinde hastaların ayak bakımına ilişkin bilgi eksikliğinin, yanlış uygulamalarının olduğu ve glisemik düzeylerinin hedef değerlerin üzerinde olduğu 
belirlenmiştir. Çalışmaya katılan hastaların eğitimden sonraki 1. ve 3. aylardaki izlemlerinde; ayak bakımı uygulamalarını doğru yapma oranlarında eğitim öncesine göre artış olduğu ve özellikle diyabetik ayak gelişimini önleyici uygulamaları eğitim öncesine göre doğru yapma oranları karşılaştırıldığında, istatistiksel olarak anlamlı artışın büyük oranda eğitimden sonraki 1. aydaki izlemlerde olduğu belirlenmiştir. Bu çalışmanın sonuçları hemşireler tarafından verilen düzenli bireysel eğitimin ve eğitim sonrası yapılan izlemin tip 2 diyabetli hastaların diyabetik ayak gelişini önleyici bakım uygulamalarını doğru yapma oranlarını artırdığını göstermektedir. Hemşireler tarafindan yapılacak düzenli, sürekli eğitimler ve izlemler, hastaların ayak bakımı hakkındaki davranışlarının iyileştirilmesinde ve komplikasyonların en aza indirilmesinde, hastalığa bilișsel-sosyal uyumunun artırılmasında ve optimal glisemik kontrolün sağlanmasında etkili bir strateji olacaktır.

Çalışma sonucunda; diyabetin ciddi kayıplar ve ekonomik yük getiren bir komplikasyonu olan diyabetik ayak gelişimini önleyici uygulamaların hastalar tarafından doğru şeklide yapılmasında eğitim ve izlemin etkili olduğu görülmüştür. Bu noktada diyabetli hastalara bakım veren hemşirelerin; hastaların ayak muayenelerini rutin olarak yapmaları, hastalara ve yakınlarına doğru ayak bakımı uygulamalarını öğretmeleri, hastaları düzenli olarak izlemeleri ve doğru uygulamaların hastaların yaşam alışkanlıkları arasına yerleşmesi için hastaları bilgilendirmeleri ve motive etmeleri önemli hemşirelik yaklaşımlarıdır. Bununla birlikte daha büyük örneklemde, randomizasyon sağlanarak benzer araştırmaların yapılması, hemşirelerin hastaya diyabetik ayak gelişimini önleyici uygulamaları öğretmesindeki engelleyici ve kolaylaştırıcı faktörlerin belirlenmesine yönelik çalışmaların yapılması hemşirelik mesleğine katkı sağlayacaktır.

\section{Teșekkür}

Bu çalışmayı yapmamız için bizlere imkân sunan Sivas Cumhuriyet Üniversitesi Sağlik Hizmetleri Uygulama ve Araştırma Hastanesi İç Hastalıkları Anabilim Dalı’na teşekkür ederiz.

\section{Etik Kurul Onayı}

Sivas Cumhuriyet Üniversitesi Girişimsel Olmayan Klinik Araștırmalar Etik Kurulundan çalıșmanın yapılmasında etik ve bilimsel sakınca bulunmadığına dair onay alınmıştır (Karar No: 2015-04/11 Tarih: 17/04/2015)

\section{Çıkar Çatışması}

Yazarların çıkar çatışması yoktur.

Finansal Destek

Çalışma için finansal destek alınmamıştır.

Yazarların Makaleye Katkı Beyanı

Çalışma konusunun belirlenmesi, literatür taraması, çalışma istatistiğinin değerlendirilmesi ve çalışmanın son gözden geçirilmesi süreci: Hatice Tel Aydın. Çalışmanın ve anketlerin düzenlenmesi ve istatistik çalışmaların yapılması, hastalarla görüşülmesi ve bilgilerin alınması, anketlerin yapılması, çalışmanın yazım aşamasında literatür araştırması ve çalışmanın tartışma kısmının yazımı: Pelin Çelik.

\section{Hakem Değerlendirmesi}

Kör hakemlik süreci ile yayınlanmaya kabul edilmiştir.

\section{KAYNAKLAR}

1. World Health Organization (WHO) (2016). Global Report on Diabetes. (http://apps.who.int/iris/ bitstream/handle/10665/204871/9789241565257_eng. pdf; jessionid=E9DD2A00BA3967A6449014FC3DF D8117?sequence=1), ss. 1-88. Accessed: 04.09.2018

2. Deribe B, Woldemichae K, Nemeral G. Prevalence and Factors Influencing Diabetic Foot Ulcer among Diabetic Patients Attending Arbaminch Hospital, South Ethiopia. J Diabetes Metab. 2014;5(1):1-7.

3. International Diabetes Federation (2019). IDF Atlas 9th edition and other resources.

4. Saltoğlu N, Kılıçoğlu Ö , Baktıroğlu S, et al. Diyabetik ayak yarası ve infeksiyonunun tanısı, tedavisi ve önlenmesi: Ulusal uzlaşı raporu. Klimik Dergisi. 2015;28(Özel Sayı 1): 2-34.

5. Demir T, Akıncı B, Yeşil S. Diyabetik ayak ülserlerinin tanı ve tedavisi. Dokuz Eylül Üniversitesi Tıp Fakültesi Dergisi. 2007;21(1):63-70.

6. Danmusa UM, Terhile I, Nasir IA, Ahmad AA, Muhammad YH. Prevalence and healthcare costs associated with the management of diabetic foot ülcer in patients attending Ahmadu Bello University Teaching Hospital, Nigeria. International Journal of Health Sciences. 2016;10(2):119-228.

7. Ibrahim A, Jude E, Langton K, Jesus FRM, Harkless LB, Gawish H. IDF Clinical Practice Recommendations on the Diabetic Foot. 2017;1-70.

8. Açar G. Diyabetik ayakta tedavi yaklaşımları ve Wagner sınıflamasını tedaviyi yönlendirmedeki rolü. T.C. Sağlık Bakanlığı Göztepe Eğitim ve Araştırma Hastanesi 2. Cerrahi Kliniği Uzmanlık Tezi. 2006.

9. Zgonis T, Stapleton J, Girard-Powell V, Hagino R. Surgical management of diabetic foot infections and amputations. AORNJ. 2008;87(5):935-950.

10. Teles PNM. Case study in treatment of diabetic foot ulcer with alimentary gelatin. Br J Nurs. 2011;20(6):S4, S6, S8.

11. Torreguitart MV. International Consensus on the Diabetic Foot. Rev Ferm. 2011;34(5):25-30.

12. National Institue for Health and Care Excellence Guideline. Diabetic Foot Problems: Prevention and Management. 2015;150.

13. Bakker K, Schaper, NC. The development of global consensus guidelines on the management and prevention of the diabetic foot. Diabetes Metab Res Rev. 2012;28 Suppl 1:116-118. 
14. Namvong T. Nursing Practice Guideline for Foot Care for Patients with Diabetes in Thailand. 2014;1-448.

15. Funnell MM, Anderson RM, Austin A, Gillespie SJ. Individualization of diabetes self management education. The Diabetes Educator. 2007;33:45-49.

16. Hannah JB, Alberts J. Motivators and barriers to attending a diabetes education class and its impact on beliefs, behaviors, and control over diabetes. Geriatric Nursing. 2005;26:50-58.

17. Mensing CR, Norris SL. Group education in diabetes: Effectivenes and implementation. Diabetes Spectrum. 2003;16:96-103.

18. American Diabetes Association (ADA). Standarts of medical care in diabetes. Diabetes Care. 2013;36(Suppl. 1):11-66.

19. Adiewere P, Gillis RB, Imran Jiwani S, Meal A, Shaw I, Adams GG. A systematic review and meta-analysis of patient education in preventing and reducing the incidence or recurrence of adult diabetes foot ulcers. Heliyon. 2018;4(5):e00614.

20. D’Souza MS, Ruppert SD, Parahoo K, Karkada SN, Amirtharaj A, Jacob D, Balachandran S, Al-Samı NM. Foot care behaviors among adults with type 2 diabetes. Prim Care Diabetes. 2016; 10(6):442-451.

21. Dorresteijin JAN, Valk GD. Patient education for preventing diabetic foot ulceration. Diabetes Metab Res Rev. 2012;28(1):101-106.

22. Adolfsson ET, Smide B, Gregeby E, Fernstrom L, Wikblad K. Implementing empowerment group education in diabetes. Patient Education and Counselling. 2004;53(3):319-324.

23. Ekore RI, Ajayi IO, Arije A, Ekore JO. Knowledge of and attitude to foot Care amongst type 2 diabetes patients attending a university based primary care clinic in Nigeria: Original research. African Primary Health Care and Family Medicine. 2010;2(1):1-3.

24. Nural N, Hintistan S. Diyabetik hastaların ayak bakımı ile ilgili bilgi ve tutumlarının incelenmesi. Anadolu Hemşirelik ve Sağlık Bilimleri Dergisi. 2015;18:2.

25. Fujiwara Y, Kishida K, Terao M, Takahara M, Matsuhisa M, Funahashi T, Shimomura I, Shimizu Y. Beneficial effects of foot care nursing for people with diabetes mellitus: An uncontrolled before and after intervention study. J Adv Nurs. 2011;67(9):1952-1962.
26. Miulescu RD, Neamtu MC, Dănoiu S, Paun D, Margina D. Prevalence of foot ulcer in diabetıc patients. Clinical Anatomy. 2014;13(3):411-412.

27. Kartal A, Çağırgan MG, Tiğlı H, Güngör Y, Karakuş N, Gelen M. Tip 2 diyabetli hastaların bakım ve tedaviye yönelik tutumları ve tutumu etkileyen faktörler. TAF PrevMed Bull. 2008;7(3):223-230.

28. D'Souza MS, Karkada SN, Hanrahan NP, Venkatesaperumal R, Amirtharaj A. Do perceptions of empowerment affect glycemic control and self-care among adults with type 2 diabetes. Glob J Health Sci. 2015;7(5):80.

29. Güner A. Diyabetik hastaların diyabetik ayakla ilgili bilgi ve tutumlarının incelenmesi. Sağlık Bakanlığı Taksim Eğitim ve Araştırma Hastanesi. Uzmanlık Tezi. 2005.

30. Policarpo NDS, Moura JRA, Melo Junior EBD, Almeida PCD, Macedo SFD, Silva ARVD. Knowledge, attitudes and practices for the prevention of diabetic foot. Revista Gaúcha de Enfermagem. 2014;35(3):36-34.

31. Göç M. Diyabetes mellituslu hastalarda hastalığın süresi, hastaların öğrenim düzeyi, diyabetik ayakla ilgili eğitim alma durumu, metabolik değerlerin, diyabetik ayak gelişim riski ve diyabetik ayaktan koruyucu davranış modelleri geliştirmeye etkileri. Sağlık Bakanlığı Haydarpaşa Numune Eğitim ve Araştırma Hastanesi. Uzmanlık tezi. 2008.

32. Türkiye Diyabet Vakfı. 2010-2020 Ulusal Diyabet Stratejisi Sonuç Dökümanı. İstanbul, Türk Diyabet Vakfı. 2010.

33. Lipsky BA, Tabak YP, Johannes RS, Vo L, Hyde L, Weigelt JA. Skin and soft tissue infections in hospitalised patients with diabetes: Culture isolates and risk factors associated with mortality, length of stay and cost. Diabetologia. 2010; 53(5): 914-923.

34. Neşe A, Ovayolu N. Diyabetik ayak ve bakımı. Atatürk Üniversitesi Hemşirelik Yüksekokulu Dergisi. 2006; 9(2):8996. 